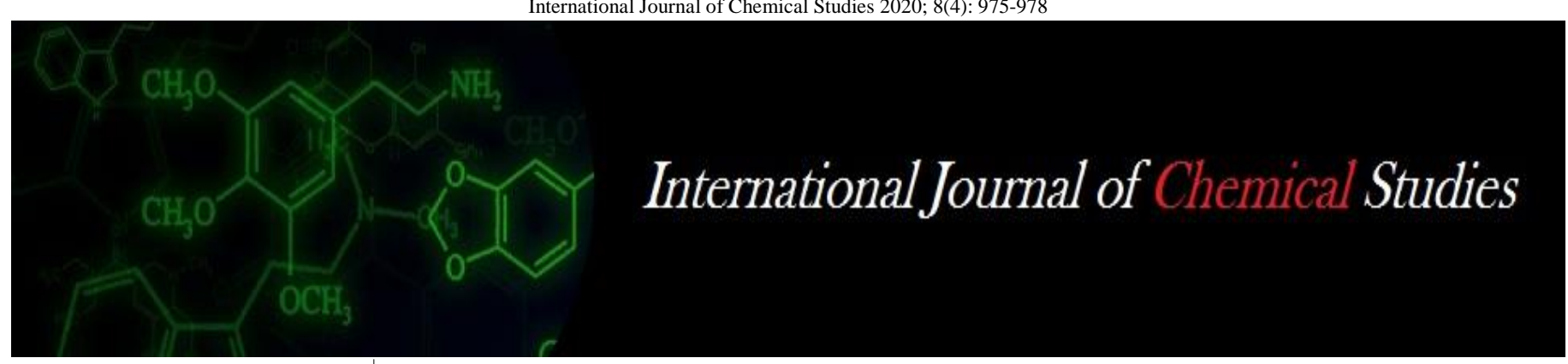

P-ISSN: 2349-8528

E-ISSN: 2321-4902

www.chemijournal.com

IJCS 2020; 8(4): 975-978

(C) 2020 IJCS

Received: 14-05-2020

Accepted: 18-06-2020

Yogesh Pate

Jawaharlal Nehru Krishi Vishwa

Vidyalaya, College of

Agriculture, Ganj-Basoda

Vidisha, Madhya Pradesh, India

Preeti Patel

S.S. Girls Govt. Degree College

Ganj-Basoda, Vidisha, Madhya

Pradesh, India

\section{PK Jaga}

Jawaharlal Nehru Krishi Vishwa

Vidyalaya, College of

Agriculture, Ganj-Basoda,

Vidisha, Madhya Pradesh, India

\section{Corresponding Author:}

Yogesh Patel

Jawaharlal Nehru Krishi Vishwa

Vidyalaya, College of

Agriculture, Ganj-Basoda

Vidisha, Madhya Pradesh, India

\section{Path analysis of environmental factors affects the population dynamics of American bollworm, Helicoverpa armigera (Hubner) lepidoptera - noctuidae in cotton}

\author{
Yogesh Patel, Preeti Patel and PK Jaga
}

DOI: https://doi.org/10.22271/chemi.2020.v8.i4g.9728

\begin{abstract}
The path analysis of environmental factors affects the population dynamics of American Bollworm (ABW), Helicoverpa arecmigera (Hubner) Lepidoptera -Noctuidae was assessed at the Jawharlal Nehru Krishi Vishwa Vidhyalaya, Cotton Research Station, Khandwa M.P. The perusal of data on the population of American bollworm, Helicoverpa armigera revealed that the pest was first come into view in the $28^{\text {th }}$ SMW i.e. Ist week of July and remained active till 51st SMW (III week of December). The peak population level was observed during $35^{\text {th }}$ SMW i.e. Ist week of September. The weather condition prevailed during the peak population viz. maximum temperature, minimum temperature, morning relative humidity, evening relative humidity, sunshine hours, wind velocity, rainfall and rainy day were $34.11^{\circ} \mathrm{C}$, $25.49^{\circ} \mathrm{C}, 76.54 \%, 39.56 \%, 8.29$ hours per day, $6.94 \mathrm{kmph}, 18.50 \mathrm{~mm}$ and 0.50 days respectively. The simple correlation studies between American bollworm eggs population and weather factors revealed that the ABW Eggs population had a significant positive correlation with minimum temperature. The multiple regression computed with eleven parameters as independent variables and $\mathrm{ABW}$ population as dependent variables was as follow $\mathrm{Y}=72.7571 .401 \mathrm{X} 1+0.027 \mathrm{X} 2+0.276 \mathrm{X} 3+0.048 \mathrm{X} 4+0.056 \mathrm{X} 5+1.517 \mathrm{X} 6-0.052 \mathrm{X} 7-$ $1.413 \mathrm{X} 8-0.624 \mathrm{X} 9+2.657 \mathrm{X} 10-0.945 \mathrm{X} 11 \quad\left(\mathrm{R}^{2}=0.772\right)$. The Path coefficient analysis revealed that minimum temperature had positive and high direct effect on $\mathrm{ABW}$ egg population, followed by spider, morning relative humidity and green lacewing respectively.
\end{abstract}

Keywords: Cotton, American bollworm, Environmental factors, Population dynamics

\section{Introduction}

Cotton (Gossypium hirsutum Linnaeus) "White Gold" is the most valuable textile fiber produced and utilized in the world from prehistoric times. It accounts for 50 per cent of the total world production of textile fiber and is commercially cultivated in 111 countries. Cotton yield per hectare in India is one of the lowest in the world and as a result the net income of the cotton growers is low ${ }^{[1]}$. Reliance on rains, a weak seed supply system, small land holding and scanty use of pests and disease management strategies are responsible for low yield in India. The problem is further compounded by world Trade Agreement that will have an impact on cotton production and marketing particularly due to termination of multi fiber agreement (MFA) and withdrawal of domestic support ${ }^{[2]}$ (Basu, 2001). Among various cardinal factors responsible for poor yield of cotton in India, the damage caused by large number of insect pests during different stages of crop growth are of prime importance. Rathod and Baporda ${ }^{\text {[3] }}$ has been estimated that about 20 to 25 percent yield losses were encountered due to the damage caused by insect pest. Dhawan ${ }^{[4]}$ recorded 162 insect species on cotton crop in India. The biotic and abiotic factor responsible for fluctuation in the pest population on cotton crop might assist in the prediction of the occurrence in a give an area. Thus, The path analysis of environmental factors affects the population dynamics of American Bollworm (ABW), Helicoverpa arecmigera (Hubner) Lepidoptera -Noctuidae was undertaken in present investigation. 


\section{Materials and Methods}

The population dynamics of American Bollworm (ABW), Helicoverpa armigera (Hubner) Lepidoptera -Noctuidae in relation to environmental factors was assessed at the Jawharlal Nehru Krishi Vishwa Vidhyalaya, Cotton Research Station, Khandwa M.P. The Cotton, Hirsutum variety JK-4 was sown in observation plot of 4000 sq. m under rain fed condition in black cotton soil during the last week of June in both the year of studied. All the normal agronomical practices recommended for the region were followed for raising the crop. No plant protection measure was taken throughout the crop season. The regular observations on the population dynamics of $\mathrm{ABW}$ was made at weekly interval by randomly selected 25 plants from first appearance of pest until its cessation. At the same time, observations on meteorological parameters viz. minimum and maximum temperature, morning and evening percent relative humidity, total rainfall per week, total rainy days per week, wind velocity ( $\mathrm{kmph}$ ) and sunshine hours per days were recorded daily. Standard meteorological Week (SMW) average of all the data collected for the pest, predator and weather parameters were calculated before statistical analysis. The data thus, collected were computed and subjected to statistical analysis ${ }^{[5]}$. All the possible correlations, multiple regression and path analysis among the environmental factors were worked out ${ }^{[6]}$.

\section{Results and Discussion \\ Population Dynamics of ABW}

The data on the population of American bollworm (Fig:1) revealed that the American bollworm, Helicoverpa armigera was first come into view in the $28^{\text {th }}$ SMW i.e. Ist week of July and remained active till 51st SMW (III week of December). The peak population level was observed (15.26 Eggs / 5 plants) during $35^{\text {th }}$ SMW i.e. Ist week of September. The weather condition prevailed during the peak population viz. maximum temperature, minimum temperature, morning relative humidity, evening relative humidity, sunshine hours, wind velocity, rainfall and rainy day were $34.11^{\circ} \mathrm{C}, 25.49^{\circ} \mathrm{C}$, $76.54 \%, 39.56 \%, 8.29$ hours per day, $6.94 \mathrm{kmph}, 18.50 \mathrm{~mm}$ and 0.50 days respectively. These finding confirm the findings of Jawalkar et al. (2004) they also reported that
American bollworm peak incidence from 36th to $41 \mathrm{st}$ meteorological week (2nd week of September to the 2nd week of October). The present findings are also in confirmedly with the findings of Pawar et al. ${ }^{[7]}$ they also noticed one peak of Helicoverpa during August to September.

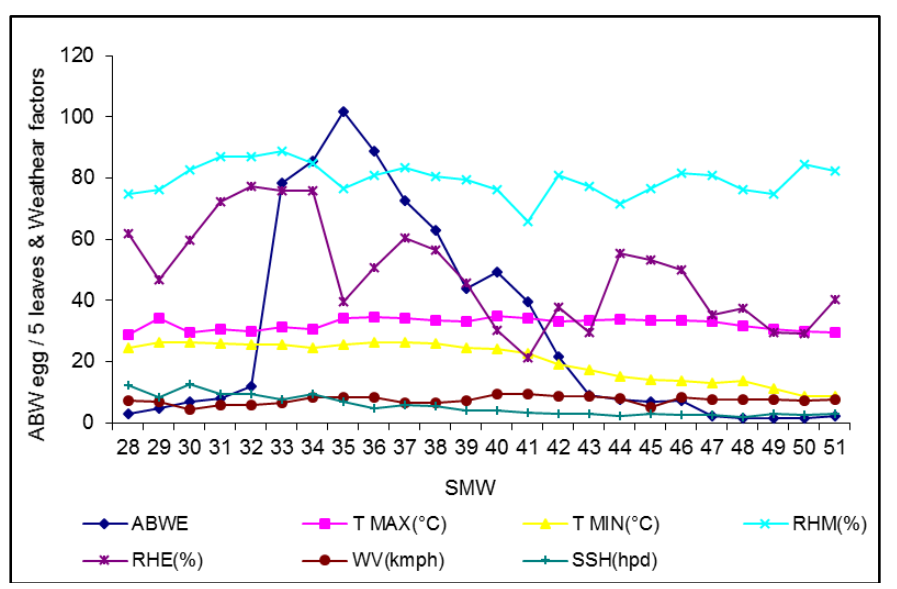

Fig 1: Influence of diferent weathear factors on the population of egg of american bollworm. (Pooled)

\section{Simple Correlation \& Regression}

The perusal of data (Table:1) on simple correlation studies between ABW population with different environmental factors revealed that the $\mathrm{ABW}$ population had a significant positive correlation with Min. tem $(\mathrm{r}=0.356)$. After $35^{\text {th }} \mathrm{SMW}$ there was a decrease in ABW eggs population. It was estimated that every unit decrease Min tem there is decrease in population of $\mathrm{ABW}$ eggs is 0.478 . The weather condition prevailed during the peak population viz. maximum temperature, minimum temperature, morning relative humidity, evening relative humidity, sunshine hours, wind velocity, rainfall and rainy day were $34.11^{\circ} \mathrm{C}, 25.49^{\circ} \mathrm{C}$, $76.54 \%, 39.56 \%, 8.29$ hours per day, $6.94 \mathrm{kmph}, 18.50 \mathrm{~mm}$ and 0.50 days respectively. These finding parallel to Vaishampayan and Veda ${ }^{[8]}$, Koushik and Naresh ${ }^{[9]}$ Bishnoi et al. ${ }^{[10]}$ and Jawalkar et al. ${ }^{[11]}$.

Table 1: Simple Correlation (r) and regression (Y) of ABW, H. armigera (Hubner) eggs population with abiotic and biotic factors

\begin{tabular}{|c|c|c|c|c|}
\hline S. No. & Character & First Year & Second Year & Pooled of two year \\
\hline 1 & $\mathrm{~T} \mathrm{MX}\left({ }^{\circ} \mathrm{C}\right)$ & $\mathrm{r}=0.398$ & $\mathrm{r}=0.373$ & $r=0.406$ \\
\hline 2 & $\mathrm{~T} \mathrm{MN}\left({ }^{\circ} \mathrm{C}\right)$ & $\mathrm{r}=0.602 * * \mathrm{Y}=-5.541+0.517 \mathrm{X}$ & $\mathrm{r}=0.532 * \mathrm{Y}=-4.19+0.401 \mathrm{X}$ & $\mathrm{r}=0.597 * \mathrm{Y}=-5.24=0.478 \mathrm{X}$ \\
\hline 3 & RHM (\%) & $\mathrm{r}=0.121$ & $\mathrm{r}=0.206$ & $\mathrm{r}=0.166$ \\
\hline 4 & RHE (\%) & $\mathrm{r}=0.174$ & $\mathrm{r}=0.299$ & $\mathrm{r}=0.240$ \\
\hline 5 & SSH (hpd) & $\mathrm{r}=0.515^{*} \mathrm{Y}=-5.134+1.366 \mathrm{X}$ & $r=-0.155$ & $\mathrm{r}=0.219$ \\
\hline 6 & WV (kmph) & $\mathrm{r}=0.213$ & $r=0.059$ & $r=0.168$ \\
\hline 7 & $\mathrm{RF}(\mathrm{mm})$ & $\mathrm{r}=0.033$ & $\mathrm{r}=0.070$ & $r=-0.405$ \\
\hline 8 & $\mathrm{RD}(\mathrm{dpw})$ & $r=-0.009$ & $\mathrm{r}=0.178$ & $\mathrm{r}=-0.431$ \\
\hline 9 & LBB (/ plants) & $\mathrm{r}=0.802 * * \mathrm{R}=2.152+0.535 \mathrm{X}$ & $\mathrm{r}=0.540^{*} \mathrm{Y}=3.793+0.318 \mathrm{X}$ & $\mathrm{r}=0.698^{*} * \mathrm{Y}=2.481+0.491 \mathrm{X}$ \\
\hline 10 & GLW (/ leaf) & $\mathrm{r}=0.825^{* *} \mathrm{Y}=1.252+0.455 \mathrm{X}$ & $\mathrm{r}=0.514$ & $\mathrm{r}=0.711 * * \mathrm{Y}=1.419+0.428 \mathrm{X}$ \\
\hline 11 & Spider (/plants) & $\mathrm{r}=0.815^{*} * \mathrm{Y}=1.852+0.509 \mathrm{X}$ & $\mathrm{r}=0.541^{*} \mathrm{Y}=3.122+0.311 \mathrm{X}$ & $\mathrm{r}=0.717 * \mathrm{Y}=2.081+0.466 \mathrm{X}$ \\
\hline
\end{tabular}

$* \& * *$ Showed significant at $5 \%$ \& $1 \%$ level of significance respectively

\section{Multiple Regression Analysis}

The multiple regression computed with eleven parameters i.e. Maximum temperature (X1), minimum temperature (X2), morning relative humidity $(\mathrm{X} 3)$, evening relative humidity (X4), sunshine hours (X5), wind velocity (X6), rainfall (X7), rainy day (X8), population of Ladybird beetle (X9), population of Green lacewing (X10) and population of Spider (X11) as independent variables and $\mathrm{ABW}$ population as dependent variables was as follow (fig:2). $\mathrm{Y}=72.7571 .401 \mathrm{X} 1+0.027 \mathrm{X} 2+0.276 \mathrm{X} 3+0.048 \mathrm{X} 4+0.056 \mathrm{X} 5+1$. $517 \times 6-0.052 \times 7-1.413 \times 8-$ $0.624 \mathrm{X} 9+2.657 \mathrm{X} 10-0.945 \times 11$

$\left(\mathrm{R}^{2}=0.772\right)$

The multiple coefficient value between the ABW population and group of variable clearly indicated that $77.20 \%$ change in $\mathrm{ABW}$ population were affected by maximum temperature, 
minimum temperature, morning relative humidity, evening relative humidity, sunshine hours, wind velocity, rainfall, rainy days, population of ladybird beetle, green lacewing and spider.

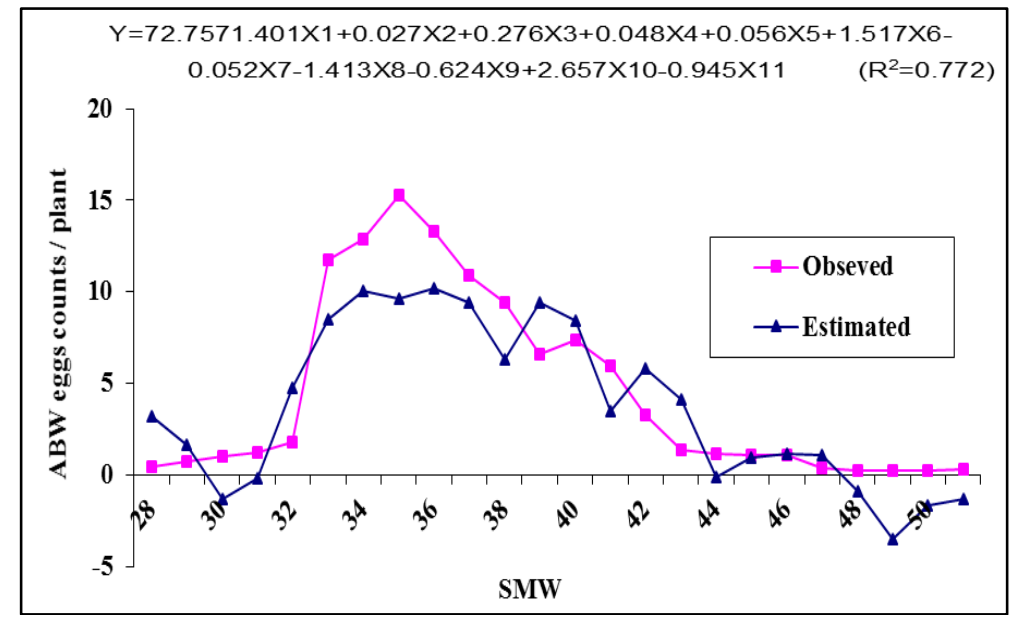

Fig 2: Mulltiple regession of certain factors on American bollworm egg population (Pooled)

\section{Path coefficient analysis}

The path coefficient analysis (Tab:2 \& Fig:3) raveled that The minimum temperature had positive and high direct effect (0.8346) followed by spider $(0.7003)$, morning relative humidity $(0.0 .3075)$ and green lacewing (0.2469) respectively. The observations revealed that the positive indirect effect of high magnitude of minimum temperature was obtained via spider (0.3161) and green lacewing (0.1082). The positive indirect effect of spider was also obtained via minimum temperature $(0.3767)$, green lacewing
(0.2427), morning relative humidity (0.0876), wind velocity $(0.0124)$ and evening relative humidity (0.000). Positive indirect effect of morning relative humidity was obtained via spider (0.1995), green lacewing (0.0645), wind velocity (0.0115) and maximum temperature (0.0006). Path coefficient effect revealed that the positive indirect effect of green lacewing was obtained via spider (0.6885), minimum temperature $(0.3660)$, morning relative humidity $(0.0803)$ and wind velocity (0.0131).

Table 2: Path coefficient Analysis of abiotic and biotic factor on ABW, H. armigera population

\begin{tabular}{|c|c|c|c|c|c|c|c|c|c|c|c|c|}
\hline & $\begin{array}{c}\mathbf{T} \mathbf{M X} \\
\left({ }^{\circ} \mathbf{C}\right)\end{array}$ & $\begin{array}{c}\mathbf{T} \text { MN } \\
\left({ }^{\circ} \mathbf{C}\right.\end{array}$ & $\begin{array}{c}\text { RHM } \\
(\%)\end{array}$ & $\begin{array}{c}\text { RHE } \\
(\%)\end{array}$ & $\begin{array}{c}\text { SSH } \\
(\mathbf{h p d})\end{array}$ & $\begin{array}{c}\mathbf{W V} \\
(\mathbf{k m p h})\end{array}$ & $\begin{array}{c}\text { RF } \\
(\mathbf{m m})\end{array}$ & $\begin{array}{c}\text { RD } \\
(\mathbf{d p w})\end{array}$ & $\begin{array}{c}\text { LBB } \\
(/ \mathbf{P l a n t s})\end{array}$ & $\begin{array}{c}\text { GLW } \\
(/ \mathbf{l e a f})\end{array}$ & $\begin{array}{c}\text { Spider } \\
(/ \mathbf{p l a n t s})\end{array}$ & $\begin{array}{c}\text { Correlation } \\
\text { Coefficient }\end{array}$ \\
\hline T MX & -0.3537 & 0.5252 & -0.0005 & 0.0000 & -0.1231 & -0.0469 & 0.0306 & 0.0120 & -0.0792 & 0.0483 & 0.1441 & 0.1568 \\
\hline T MN & -0.2225 & 0.8346 & -0.0039 & -0.0002 & -0.0532 & -0.0800 & -0.2489 & -0.0280 & -0.1812 & 0.1082 & 0.3161 & $0.4411^{* *}$ \\
\hline RHM & 0.0006 & -0.0105 & 0.3075 & -0.0002 & -0.0183 & 0.0115 & -0.1359 & -0.0302 & -0.1163 & 0.0645 & 0.1995 & 0.2722 \\
\hline RHE & -0.0146 & 0.3008 & 0.1454 & -0.0005 & 0.0195 & -0.0505 & -0.2093 & -0.0336 & -0.0059 & -0.0030 & 0.0071 & 0.1554 \\
\hline SSH & -0.2774 & 0.2827 & 0.0358 & 0.0001 & -0.1570 & -0.0201 & 0.1679 & 0.0263 & -0.0754 & 0.0508 & 0.1444 & 0.1780 \\
\hline WV & -0.1619 & 0.6515 & -0.0346 & -0.0002 & -0.0308 & -0.1025 & -0.2237 & -0.0146 & 0.0419 & -0.0316 & -0.0848 & 0.0086 \\
\hline RF & 0.0519 & 0.2860 & 0.1138 & -0.0002 & 0.0564 & -0.0491 & -0.4669 & -0.0596 & -0.1136 & 0.0593 & 0.1814 & 0.1654 \\
\hline RD & 0.0519 & 0.2860 & 0.1138 & -0.0002 & 0.0505 & -0.0183 & -0.3405 & -0.0817 & -0.1256 & 0.0687 & 0.2092 & 0.2140 \\
\hline LBB & -0.0719 & 0.3883 & 0.0918 & 0.0000 & -0.0304 & 0.0110 & -0.1361 & -0.0263 & -0.3896 & 0.2405 & 0.2092 & $0.7736^{* *}$ \\
\hline GLW & -0.0692 & 0.3660 & 0.0800 & 0.0000 & -0.0323 & 0.0131 & -0.1121 & -0.0227 & -0.3794 & 0.2469 & 0.6885 & $0.7790^{* *}$ \\
\hline Spider & -0.0728 & 0.3767 & 0.0876 & 0.0000 & -0.0324 & 0.0124 & -0.1209 & -0.0244 & -0.3874 & 0.2427 & 0.7003 & $0.7819^{* *}$ \\
\hline
\end{tabular}

Residual $=0.5373, * \& * *$ Showed significant at $5 \% \& 1 \%$ level of significance respectively, The bold figures denote the direct effect of different factors on population of pest

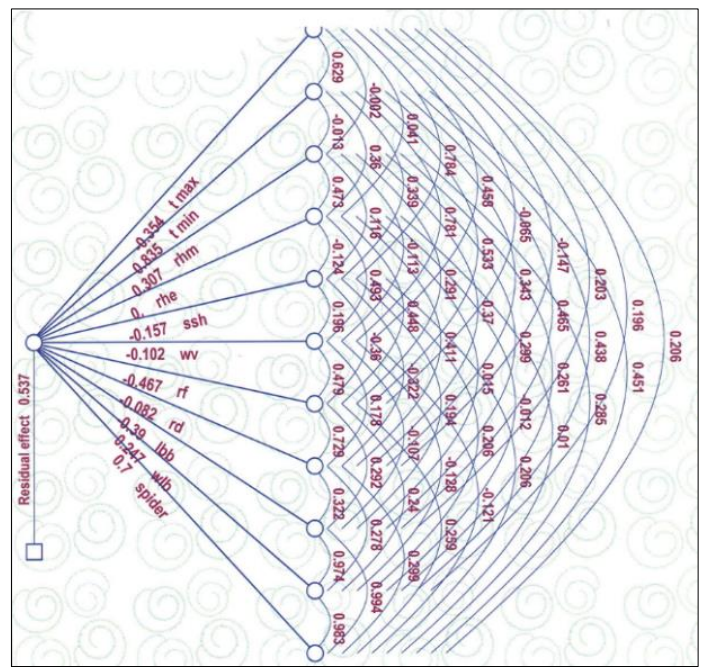

Fig 3: Phenotypical path diagram showing influence of various factors on the population of American bollworms 


\section{Conclusion}

In the present investigation, it can be concluded that environmental factors play the critical role for build up the population of $\mathrm{ABW}$. The multiple linear regression analysis raveled that the major climatic factors together were responsible for a total variation of $77.20 \%$ in $\mathrm{ABW}$ population. Mild rainfall with mild to high temperature (25 to $34{ }^{\circ} \mathrm{C}$ ) and high humidity $(>60 \%)$ were congenial for the multiplication of the pest.

\section{Acknowledgement}

The authours are grateful to Indian Metrological Department, Pune and also to the Director Research, Jawaharlal Nehru Agriculture University, Jabalpur M.P. for technical support for this study.

\section{References}

1. Anonymous. All India Coordinated cotton improvement project annual report, Coimbatore. 2004: 2-6

2. Basu AK. Impact of WTO on cotton and textile. National journal of plant improvement. 2001; 3:6-10.

3. Rathod RR, Bapodra JG. Relative toxicity of various insecticides to coccinellid predators in cotton. Indian Journal of Plant Protection. 2006: 30(1):29-31.

4. Dhawan AK. Impact of some new insecticides on natural enemy complex of cotton ecosystem. Pestology. 2001; 24(5):8-15.

5. Panse VG, Sukhatme PV. Statistical methods for Agricultural Research. ICAR, New Delhi, 1985.

6. Gomez KA, Gomez AA. Statistical Procedures for Agricultural Research (IInd edition), An International Rice Research Institute, A wiba -International publication, John willey and sons, New York, 1984, 680.

7. Pawar CS, Srivastava CP and Reed W. Some aspects of population dynamics of $H$. armigera Hubner. Paper presented in III Oriental Entomology Symposium, 21-24, Feb. at University of Kerala Kariavattom Kerala India, 1984, 1-9

8. Vaishampayan SM, Veda OP. Population dynamics of gram podborer, Helicoverpa armigera (Hubner) and its outbreak situation on gram, Cicer aerietinum L. at Jabalpur. Indian Journal of Entomology: 1980; 42(3):453-459.

9. Kaushik SK, Naresh JS. Population dynamics distribution pattern and damage of Heliothis armigera Hubner on chickpes. Indian Journal Agriculture Science. 1984; 54(4):325-328.

10. Bishnoi OP, Mohan Singh, Rao Vum, Ram Niwas Sharma, Singh PD, Niwas R et al. Population dynamics of cotton pest in relation to weather parameters. Indian journal of Entomology. 1996; 58(2):103-107

11. Jawalkar SC, Daware DG, Awaz HB, Badgujar MP. Incidence of American bollworm (Helicoverpa armigera) (Hub.) and its relation with ecological factors. Journal of Maharashtra Agricultural Universities. 2004; 29(1): 9799. 